\title{
JUURNAL.RU
}

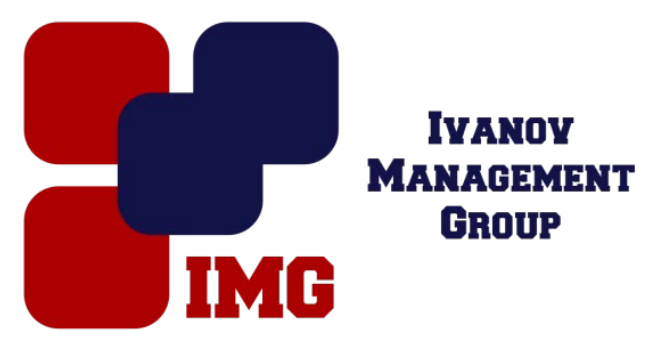

Климовских Н.В., Костенко В.В. Кубанский Государственный аграрный университет имени И. Т. Трубилина Краснодар, Россия

doi: 10.18411/lj-30-04-2017-1-14

idsp 000001:lj-30-04-2017-1-14

\section{Особенности управления коммерческой организацией на международном уровне}

\section{Аннотация}

В данной статье рассмотрены характерные черты управления бизнесом на международном рынке. Проанализированы содержание и формы международной деятельности организации. Выявлены особенности управления коммерческим предприятием на международном уровне. На основе проведенного исследования предлагается ознакомиться с особенностью управления на международном уровне, дается определение, формируются основные характеристики управления на международном уровне.

Ключевые слова: бизнес, международный рынок, международная деятельность организации.

На сегодняшний день международный бизнес является всепроникающим и быстрорастущим феноменом [1]. Международный бизнес это прежде всего деловое взаимоотношение частных предприятий либо их подразделений, находящихся в разных странах. Базируется он именно на возможности получения выгоды из межстрановых деловых операций, то есть тот факт, что продажи в другой стране, или осуществление производства предприятия одной страны в другой, или предоставление услуг на территории другой страны будет более эффективно чем в своей стране [4].

Для достижения поставленных целей предприятию всегда требуется использование определенного количества ресурсов (материальных, человеческих, финансовых и информационных). И эффективным 
распоряжением требуемых ресурсов занимается менеджмент. Основными чертами, характеризирующими международный менеджмент, является интернационализация и глобализация бизнеса.

Международный менеджмент - это вид менеджмента, основной целью которого являются формирование, развитие и использование конкурентных преимуществ предприятия за счет ведения бизнеса в разных странах и соответствующего использование экономических, демографических, культурных, социальных и прочих особенностей таких стран.

Интернационализация - это направленная на рост географическая дисперсия коммерческой деятельности предпринимательства через государственные границы [2].

Глобализация - это процесс укрепление связей и влияния в мировом масштабе, который заключается в том, что:

1. Все более крупным становится перемещение капиталов, людей, товаров и информации.

2. Возрастает восприимчивость индивидуальных стран к обусловленности и воздействиям международной среды.

Все большее количество предприятий переходит на глобальный масштаб. В погоне за иностранными конкурентами, они пытаются все больше осуществлять производство и продажи на основных зарубежных площадках [3].

Глобализация в свою очередь характеризуется следующими особенностями:

- росту прямых инвестиций зарубежного капитала;

- росту объемов внутрифирменной торговли, производство компонентов в одной стране и экспорт их в другую;

- созданием союзов, различных альянсов и совместных компаний с другими транснациональными компаниями, либо с компаниями местного уровня.

Под основными факторами глобализации стоит выделять: рыночные, финансовые, технологические, правовые и политические, культурные и экологические.

Разберём их по порядку:

- рыночные факторы, касаются рынков и стратегий конкуренции на глобальном уровне;

- финансовые, связаны с перемещением на глобальном уровне капитала, денег и трансфера собственности; 
- под технологическими факторами, стоит понимать глобализацию исследований, внедрению новшеств и технологий;

- правовые и политические, свод факторов, касающихся проблемы правового регулирования, методов управление на глобальном уровне и введению социальных, экономических и политических систем под единую мировую систему;

- культурные, это слияние стилей жизни и моделей потребления в глобальном масштабе и создание единого сознания и культуры;

- экологические, это те факторы, которые характеризуют взаимоотношения человека с окружающей средой и ее состояние.

В основе управления международной деятельности фирмы лежит определенная совокупность стратегических решений. Эффективное управление фирмой будет зависеть от рационально составленной совокупности, то есть:

- охват ключевых моментов, связанных с внешними отношениями фирмы, вне зависимости от принятой в ней организационной структуры управления;

- дает возможность для последовательной реализации стратегических целей на уровне текущих планов в деятельности организации;

- отсутствие внешних и внутренних противоречий;

- ориентированность на оценку развития ситуации.

Исполнение первых трех пунктов дает право считать такую совокупность целостной. Другими словами, при невыполнении любого из этих пунктов ставит под сомнение наличие рационального стратегического планирование на данном предприятии. Плюс ко всему, только при выполнении с последним пунктом дает право считать эту систему действительно эффективной и соответствующей современным потребностям в управлении.

Таким образом, приведенные данные позволяют утверждать, что система управления большинства Российских фирм является сыроватой для соответствия мировым стандартам. Только из-за этого ослабляются их позиции на международных торговых площадках. Нельзя не согласиться что бывшие социалистические страны долгое время были отрезаны от глобального рынка и его требований. Единственным путем развития на данный момент является увеличение интенсивности зарубежных хозяйственных связей, плотное вхождение в мировые экономические отрасли. Для помощи в этом и служит 
управление, которое и является основным факторов во все более глобализирующейся экономике.

1. Управление международной организацией [Электронный ресурс]: https://author24.ru/spravochniki/menedzhment/suschnost_upravleniya_v_rynochnoy_ekono mike/upravlenie_mezhdunarodnoy_organizaciey/

2. И.В. Багрова «Внешнеэкономическая деятельность предприятий» Учебник. - К: Центр учебной литературы, 2004. - 121с

3. Процесс глобализации и управление предприятием [Электронный ресурс]: http://evolutio.info/content/view/533/53/

4. Международный

бизнес

[Электронный pecypc]: http://www.upravlenie24.ru/interbisness.htmhttp://www.upravlenie24.ru/interbisness.htm 